\title{
Physico-chemical characterisation of some samples of fresh milk and milk powder
}

\author{
Alina SOCEANU, Viorica POPESCU* and Simona DOBRINAS \\ Department of Chemistry and Chemical Engineering, ,, Ovidius” University of Constanta, 124 Mamaia Blvd., \\ Constanta 900527, Romania
}

\begin{abstract}
Milk consumption is important in the diet of all age groups because it provides important nutrients that are essential for humans. Children are the largest consumers of milk, thus, it's very important that milk is free of toxic compounds that can be harmful for humans. Aim of the study was to determine the physico-chemical characteristics of some samples of milk powder for different stage of baby growing and for some samples of fresh milk: raw cow's milk, milk trade and UHT type. The following physico-chemical properties: density, $\mathrm{pH}$, acidity, the presence of acetone, enzymes, antiseptics, dry substance, the ash, total fat, saponification and peroxide index, total nitrogen and protein content were determined. Comparing the values of acidity for analyzed samples it can be concluded that the powder milk acidity value is much lower than the fresh milk. The presence of antiseptics and acetone was not identified, and amylase and peroxidase were found only in raw cow's milk. The highest protein content was found for milk powder $(27.22 \%)$.
\end{abstract}

Keywords: fresh milk, milk powder, acidity, protein, peroxide index.

\section{Introduction}

Milk is a fluid with nutritional, immunological and anti-inflammatory effects that protects the health of children [1, 2]. Milk composition includes antioxidant compounds, enzymes, peroxidase, catalase, lactoferrin, coenzyme Q10 [3 - 5]. Also the milk's contamination with phenols, pesticides and heavy metals was studied [6 - 8].

Milk powder has attractive physical and functional properties that depend on the raw milk composition, the degree of standardization, the processing and subsequent storage conditions [9].

Aim of the study was to determine some physicochemical characteristics of 5 samples of milk powder for different stage of baby growing (0-6 months; 6 months; 10 months; 1 year; more than 2 years) and for 3 samples of fresh milk: raw cow's milk, milk trade and UHT type.

\section{Experimental}

\subsection{Samples and sample preparation}

The studied products, purchased from the local market were 5 samples of milk powder for different stage of baby growing and for 3 samples of fresh milk: raw cow's milk- sample 6, milk trade -sample 7 and UHT type -sample 8.

\footnotetext{
* Corresponding author: vpopescu@ univ-ovidius.ro
}

Throughout the analyzing process, the samples have been kept at room temperature in appropriate, sealed containers.

\subsection{Reagents and solutions}

All reagents were of analytical-reagent grade (Merck) and all solutions were prepared using deionized water. The working solutions used for different determinations/ measurements were as follows: $\mathrm{KOH} 0.1 \mathrm{~N}$ for acidity index, $\mathrm{HCl} 0.5 \mathrm{~N}$ for saponification index, $\mathrm{HCl} 0.1 \mathrm{~N}$ for protein content and $\mathrm{Na}_{2} \mathrm{~S}_{2} \mathrm{O}_{3} 0.01 \mathrm{~N}$ for peroxide index.

\subsection{Methods of analysis}

Density was determined using the pycnometer method and the $\mathrm{pH}$ value has been determined using a pH-meter PH220 from Extech Instruments.

Methods of determination for acidity, saponification index and peroxide index were presented in a previous paper [10].

Dry matter determination. The dry matter means all substances that remain after evaporating water from any product. Changes in milk dry matter content is determined by the variation of its components. By determining dry matter, the quality of milk and his forgeries are established.

$10 \mathrm{~g}$ of sand was introduced in a weighing vial and dried in an oven at $102{ }^{\circ} \mathrm{C}$. It was cooled in a desiccator and then weighed. In the vial $10 \mathrm{~cm}^{3}$ of milk was placed and weighed again. The milk with sand were mixed and heated to $50-60{ }^{\circ} \mathrm{C}$ in the oven 
for 2-3 hours, stirring occasionally until a crumbly mass was obtained. Then the drying was continued in an oven at $102{ }^{\circ} \mathrm{C}$ for 4 - 5 hours, and after cooling in the desiccator the vial is weighed [11].

The dry matter (D.M.) was calculated using the formula:

$$
\text { D. M. } \%=\frac{m_{2}-m_{0}}{m_{1}-m_{0}} \times 100
$$

$m_{\mathrm{o}}=$ mass of vial $(\mathrm{g})$;

$m_{2}=$ mass of vial with product after drying $(\mathrm{g})$;

$m_{1}=$ mass of vial with product before drying $(\mathrm{g})$ [11].

The ash content. The ashes represent non-volatile milk minerals.

The method was based on residue calcination obtained by evaporating on the water bath to dryness of a quantity of milk. $1.5 \mathrm{~g}$ of milk / milk powder in a porcelain capsule was weighed, few drops of acetic acid were added and protein precipitation was evaporated on water bath to dryness. The residue was calcined in an electric furnace at a temperature of about $500{ }^{\circ} \mathrm{C}$.

The amount of ash was calculated using the equation:

$$
\text { Ash content } \%=\frac{m_{2}-m}{m_{1}-m} \times 100
$$

$m=$ weight of the crucible $(\mathrm{g})$;

$m_{1}=$ weight of crucible with milk $(\mathrm{g})$;

$m_{2}=$ weight of crucible with milk after calcination (g) [11].

Total fats content. To determine the fat content of milks $1 \mathrm{~g}$ of sample was weighed and placed in a conical flask with $10 \mathrm{~cm}^{3}$ of ethanol and $4 \mathrm{~cm}^{3}$ of hydrochloric acid $0.1 \mathrm{~N}$. The mixture was heated to boiling on water bath with reflux cooler, until the phase separation, then $5 \mathrm{~cm}^{3}$ of hot water and $10 \mathrm{~cm}^{3}$ of ethanol were added with few drops of $1 \%$ methyl orange. $2 \mathrm{~g}$ of paraffin was added and the mixture was heated on water bath, stirring from time to time with a baton, until complete melting of paraffin and separating content in two layers.

After cooling, paraffin was removed and washed with water to neutral reaction. Paraffin was dried on filter paper and then placed in a beaker, brought to the table constant drying in the oven at $105 \pm 5{ }^{\circ} \mathrm{C}$. The glass with paraffin was dried to constant mass in the oven at $105 \pm 5{ }^{\circ} \mathrm{C}$.

The total fat content (F.C.) was calculated using the formula:

$$
\text { F.C. } \%=\frac{m_{2}-m_{1}}{m} \times 100
$$

$m_{2}=$ mass of obtained paraffin $(\mathrm{g})$;

$m_{1}=$ mass of added paraffin $(\mathrm{g})$;

$m=$ mass of the sample taken for determination

(g) [11].

The presence of ketones (especially acetone) may occur due to digestive disorders that alter metabolism of carbohydrates and lipids. The presence of acetone can be appreciated after reaction with sodium nitroprusside in ammoniacal medium when it forms a purple complex, which we compare with the standard scale [11].

The fact that amylase and peroxidase are destroyed at temperatures below $100{ }^{\circ} \mathrm{C}$, their absence or presence in milk can deduce if the milk is pasteurized or not. The presence of amylase in milk can be verified with tincture of iodine using starch [11].

Peroxidase was inactivated at temperatures above $80{ }^{\circ} \mathrm{C}$. Peroxidase in milk breaks down hydrogen peroxide into water and atomic oxygen and will oxidize phenols or aromatic amines, giving colored compounds. A gray-blue color indicate that the milk is unpasteurized or is a raw milk [11].

Antiseptic substances adds in milk prevent the development of microorganisms and especially those that increase the acidity of milk, either by neutralizing lactic acid formed [11].

The most widely used antiseptics are: boric acid, salicylic acid, formaldehyde, hydrogen peroxide and sodium carbonate.

Salicylic acid has been identified if a violet coloration was obtained using a dilute solution of $\mathrm{FeCl}_{3}[11]$.

Hydrogen peroxide is an unstable compound, its presence can be detected only as long as it is not completely decomposed. The presence of hydrogen peroxide can be carry out by reaction with potassium dichromate, when should appears a blue-green ring. The color intensity is proportional to the concentration of $\mathrm{H}_{2} \mathrm{O}_{2}$ [11].

Protein content. Protein content was obtained using the Kjeldahl method [12]. The samples were digested by heating it in the presence of sulfuric acid. Digestion converts any nitrogen in the food into ammonia, and other organic matter to $\mathrm{CO}_{2}$ and $\mathrm{H}_{2} \mathrm{O}$.

The solution in the digestion flask was made alkaline by addition of sodium hydroxide, which converts the ammonium sulfate into ammonia gas. The ammonia gas that was formed was liberated from the solution and moved out of the digestion flask into the receiving flask - which contains an excess of boric acid. The nitrogen content was estimated by titration of the ammonium borate formed with hydrochloric acid $0.1 \mathrm{~N}$. A blank sample was used at the same time to take into account any residual nitrogen which may be in the reagents used to carry out the analysis [12].

Total nitrogen content of the milk was estimated using the formula:

$$
\% N=\frac{1.4007 \cdot C_{H C l} \cdot\left(V-V_{b}\right)}{m}
$$

$C_{\mathrm{HCl}}=$ the concentration of $\mathrm{HCl}$;

$V=$ the volume of $\mathrm{HCl}$ used for titration of the sample $(\mathrm{mL})$;

$V_{\mathrm{b}}=$ the volume of $\mathrm{HCl}$ used for titration of the blank sample $(\mathrm{mL})$;

$m=$ the mass of digested sample $(\mathrm{g})$. 
Based on the relationship of obtaining nitrogen concentration, protein content can be determined using the equation:

$$
\text { Protein content }=\% \mathrm{~N} \cdot 6.38
$$

\section{Results and Discussions}

The results for density, $\mathrm{pH}$ and acidity are presented in Table 1.

Table 1. The values of density, $\mathrm{pH}$ and acidity for studied samples.

\begin{tabular}{|c|c|c|c|}
\hline Samples & Density & $\mathrm{pH}$ & Acidity $\left({ }^{0} \mathrm{~T}\right)$ \\
\hline 1 & 1.0376 & 6.58 & 5 \\
\hline 2 & 1.0484 & 6.62 & 9 \\
\hline 3 & 1.0414 & 6.59 & 8 \\
\hline 4 & 1.041 & 6.79 & 10 \\
\hline 5 & 1.0416 & 6.67 & 9 \\
\hline 6 & 1.0278 & 6.79 & 14 \\
\hline 7 & 1.0315 & 6.85 & 19 \\
\hline 8 & 1.0304 & 6.82 & 16 \\
\hline
\end{tabular}

The $\mathrm{pH}$ values were around 6.5 - 6.8. Comparing the values of acidity for analyzed samples it can be concluded that the powder milk acidity value is much lower than the fresh milk.

The results for dry matter, ash, total fat, saponification and peroxide indices are presented in Table 2.

Table 2. The values of dry matter, ash, total fat, saponification and peroxide indices for studied samples.

\begin{tabular}{|c|c|c|c|c|c|}
\hline $\begin{array}{c}\text { Sam } \\
\text { ples }\end{array}$ & $\begin{array}{c}\text { Dry } \\
\text { matter } \\
(\%)\end{array}$ & $\begin{array}{c}\text { Ash } \\
(\%)\end{array}$ & $\begin{array}{c}\text { Total } \\
\text { fat } \\
(\%)\end{array}$ & $\begin{array}{c}\text { Saponificat } \\
\text { ion index } \\
(\mathrm{mg} \\
\mathrm{KOH} / \mathrm{g} \\
\text { product })\end{array}$ & $\begin{array}{c}\text { Peroxide } \\
\text { index } \\
(\mathrm{meq} / \mathrm{g} \\
\text { product })\end{array}$ \\
\hline 1 & 10 & 6.47 & 25 & 30 & 25 \\
\hline 2 & 3 & 6.47 & 23 & 30 & 31 \\
\hline 3 & 4 & 6.45 & 22 & 33 & 27 \\
\hline 4 & 4 & 6.39 & 22 & 36.4 & 28 \\
\hline 5 & 2 & 6.43 & 20 & 36.2 & 28 \\
\hline 6 & 41 & 1.1 & 3.9 & 8 & 1 \\
\hline 7 & 20 & 1.9 & 2.4 & 1.4 & 3 \\
\hline 8 & 31 & 1.7 & 1.7 & 2.8 & 1 \\
\hline
\end{tabular}

The ash content was six times higher in milk powder that in fresh milk and the total fat varied from $22-25 \%$ for powder milk while in fresh milk the UHT type has the lowest percentage of fat $(1.7 \%)$.

The acetone was not found in studied samples while peroxidase and amylase were present only in raw cow's milk. Salicylic acid and hydrogen peroxide were not found in studied sample of milk.

In Fig. 1 are presented the total nitrogen content and the protein content for the studied samples.

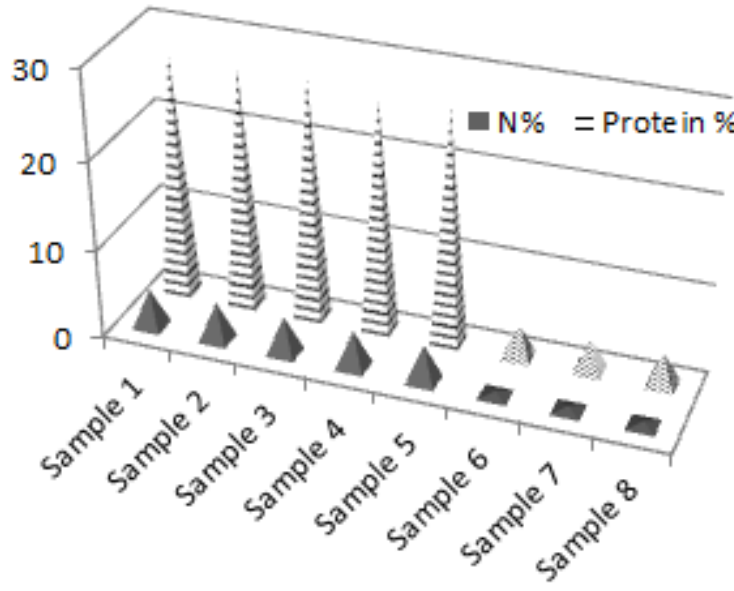

Figure 1. Protein and total nitrogen content for the studied samples

In powder milk samples, nitrogen content was between $4.0956 \%$ and $4.2664 \%$ with the protein content varied from $26.13 \%$ to $27.22 \%$. In cow's milk the protein content was between $3.44 \%$ and $3.64 \%$.

\section{Conclusions}

For the studied samples of fresh milk and powder milk the $\mathrm{pH}$ values varied from 6.5 to 6.8 and the ash content was six times higher in milk powder that in fresh milk. Comparing the values of acidity for analyzed samples it can be concluded that the powder milk acidity value is much lower than the fresh milk. The presence of antiseptics and acetone was not identified, and amylase and peroxidase were found only in raw cow's milk. The highest protein content was found for milk powder $(27.22 \%)$. It can be concluded that studied samples are safety for human consumption.

\section{References}

[1]. C. Velázquez Vázquez, M. Guadalupe Villa Rojas, C. Alvarez Ramírez, J.L. Chávez-Servín, T. García-Gasca, R. A. Ferriz Martínez, O.P. García, J. L. Rosado, C.M. López-Sabater, A.I. Castellote, H. M. Andrade Montemayor and K. de la Torre Carbot, Food Chemistry 176, 480 (2015).

[2]. O. Guneser and Y. Y. Karagul, Journal of Dairy Science 95, 6230 (2012).

[3]. J. Barlowska, M. Szwajkowska, Z. Litwinczuk, and J. Krol, Comprehensive Reviews in Food Science and Food Safety 10, 291 (2011).

[4]. E. Albera and M. Kankofer, Reproduction in Domestic Animals 44, 606 (2009).

[5]. A. J. Pandya and K. M. Ghodke, Small Ruminant Research 68, 193 (2007).

[6]. J.S.F. Pereira, L.S.F. Pereira, L. Schmidt, C. M. Moreira, J. S. Barin and E.M.M. Flores, Microchemical Journal 109, 29 (2013). 
[7]. S.G. Capar, W.R. Mindak and J. Cheng, Anal. Bioanal. Chem. 389, 159 (2007).

[8]. E. M. Shakera and E. E. Elsharkawy, Environmental toxicology and pharmacology 39, 433 (2015)

[9]. V. Rimpiläinen, J. P. Kaipio, N. Depree, B. R. Young, and D. I. Wilson, Journal of Food Engineering 153, 12 (2015).
[10]. V. Popescu, A. Soceanu and L. Teliban, Ovidius University Annals of Chemistry 17 (1), 91-94 (2006).

[11]. D. Mihele, Sanitary Chemistry, Practical Work (in Roumanian), Bucharest, 1998

[12]. Instruction manual of Kjeldahl system

Received: 18 June 2015

Received in revised form: 20 July 2015

Accepted: 31 July 2015 